\title{
Internationalization of Higher Education: A Stakeholder Approach
}

\author{
Suresh Kumar P. M. \\ Professor, Department of Sociology and Social Work, Christ University, Bangalore, India. \\ ORCID: 0000-0002-9540-0909

\section{P. S. Aithal} \\ Professor, College of Management \& Commerce, Srinivas University, Mangalore, India. \\ ORCID: 0000-0002-4691-8736
}

\begin{abstract}
Internationalization in higher education has been catching up as a trend receiving attention more recently than before. Academia, institutions, scholars, parents, host nations, and home countries all constitute a vicious circle of stakeholders who play a role in internationalization. Each of them has something to take and something to give, and all of them stand to benefit from it. Internationalization is achieved through various means. By opening up their border for Foreign Direct Investment (FDI) in higher education, countries navigate their opportunities to connect with foreign universities. However, this is limited by political decisions. Moreover, all of what constitutes a learning environment cannot be cloned and eventually miss out on the real experience that you get there. The alternative is to further the educational 'migration', cost and affordability notwithstanding. In both the former and the latter, the stakeholders are key instruments in the process. Therefore, any attempt to study internationalization should take into account a stakeholder perspective to examine the advantages and benefits which might accrue to them, more so the constraints and disadvantages. This would necessitate a systemic analysis of both types of supporting systems that favour internationalization. This paper aims to narrate a stakeholder perspective. An attempt is made to examine the key stakeholder issues and critical constituent elements that need to be addressed to facilitate internationalization. Internationalization as a global ranking parameter for educational institutions and its relation with gross enrolment ratio (GER) is also discussed.
\end{abstract}

Keywords: Internationalization, Stakeholder analysis, Global ranking, Gross Enrollment Ratio, Inbound and Outbound supportive system

\section{INTRODUCTION:}

Expanding educational opportunity coupled with the quest for quality and value, bringing internationalization in higher education to the fore. Various stakeholders emerge. Institutions as a stakeholder are characterised by faculty profile, infrastructure and facility, quality and standards, admission policies, ability to finance, tradition and popularity (de Wit, 2011). The state comes into the picture as a stakeholder exercising influence through rules and regulations such as visa and immigration, funds and foreign exchange norms. Students as stakeholders are marked by their interest and aptitude, ability to support on one's own. The expertise, research contribution and publication record marks the role of faculty as a stakeholder. Parents are stakeholders who invest concern and hope and to whom students look for encouragement and support. This apart, education as an instrument is decisively characterised by its quality and standards, innovation in pedagogy, ability to impart skills and transform the learners (Gatfield\& Chen, 2006), Aithal 
\&Shubhrajyotsna, 2020). All these stakeholders are equally invincible instruments impacting internationalization. A stakeholder approach, therefore, becomes important in the study of internationalization (Altbach et al, 2009).

\section{RELATED LITERATURE REVIEW:}

To know the current status in the internationalization of higher education and related factors, an extensive literature review based on keywords using Google scholar was attempted. The relevant information published in scholarly papers with a focus on research and the references is listed in table 1.

Table 1: Relevant Published works in the area of Internationalization of Higher Education

\begin{tabular}{|c|c|c|c|}
\hline $\begin{array}{l}\text { S. } \\
\text { No. }\end{array}$ & Topic & Focus & Reference \\
\hline 1 & $\begin{array}{l}\text { Changing debate on } \\
\text { internationalisation of } \mathrm{HE}\end{array}$ & $\begin{array}{l}\text { Emergence of } \\
\text { stakeholders }\end{array}$ & Teichler, (2004) \\
\hline 2 & $\begin{array}{l}\text { Country differences in the } \\
\text { internationalization of } \mathrm{HE}\end{array}$ & State as a stakeholder & Nicolescuet al. (2009) \\
\hline 3 & $\begin{array}{l}\text { Internationalization of HE: } \\
\text { Findings from a world survey }\end{array}$ & $\begin{array}{l}\text { The Global picture of } \\
\text { Internationalization }\end{array}$ & Maringe (2010) \\
\hline 4 & $\begin{array}{l}\text { Pedagogical dimension of } \\
\text { internationalisation for } 21^{\text {st }} \\
\text { century }\end{array}$ & $\begin{array}{l}\text { Role of the } \\
\text { educational system }\end{array}$ & Wihlborg (2009) \\
\hline 5 & $\begin{array}{l}\text { Graduate attributes and the } \\
\text { internationalized curriculum- } \\
\text { based better output }\end{array}$ & $\begin{array}{l}\text { Learners and their } \\
\text { perspectives }\end{array}$ & Jones \& Killick (2013) \\
\hline 6 & $\begin{array}{l}\text { Globalization and the university: } \\
\text { Myths and realities in an } \\
\text { unequal world }\end{array}$ & $\begin{array}{l}\text { Expanding the scope } \\
\text { of Institutions }\end{array}$ & Altbach(2004) \\
\hline 7 & $\begin{array}{l}\text { Transforming higher education in } \\
\text { whose image? }\end{array}$ & $\begin{array}{l}\text { Changing roles and } \\
\text { stereotypes }\end{array}$ & Deem et al. (2008) \\
\hline 8 & $\begin{array}{l}\text { Cross border } \mathrm{HE} \text { in India: False } \\
\text { understandings and true } \\
\text { overestimates }\end{array}$ & $\begin{array}{l}\text { Shared } \\
\text { understandings from } \\
\text { the Indian context }\end{array}$ & Stella\&Gnanam(2005) \\
\hline 9 & $\begin{array}{l}\text { Multilevel determinants of } \\
\text { internationalization rationales }\end{array}$ & $\begin{array}{l}\text { Exploring the } \\
\text { rationale of } \\
\text { participation }\end{array}$ & Seeber et al. (2016) \\
\hline 10 & $\begin{array}{l}\text { Successful internationalization } \\
\text { processes in business schools }\end{array}$ & $\begin{array}{l}\text { Institutional } \\
\text { experiences }\end{array}$ & Bradfordet al. (2017) \\
\hline 11 & $\begin{array}{l}\text { Finding next wave in } \\
\text { internationalization of } \mathrm{HE}\end{array}$ & $\begin{array}{l}\text { Looking towards the } \\
\text { future }\end{array}$ & Aziz\&Abdullah(2014) \\
\hline 12 & $\begin{array}{l}\text { Internationalization of } \mathrm{HE} \text { - Past } \\
\text { and future. }\end{array}$ & $\begin{array}{l}\text { Best practices in } \\
\text { Internationalization }\end{array}$ & $\begin{array}{l}\text { Knight } \quad \text { \&De } \quad \text { Wit } \\
(2018)\end{array}$ \\
\hline 13 & $\begin{array}{l}\text { Capacity building for } \\
\text { transnationalisation of } \mathrm{HE}\end{array}$ & $\begin{array}{l}\text { Translating } \\
\text { experience to action }\end{array}$ & Shams\&Hasan (2020) \\
\hline
\end{tabular}

\section{OBJECTIVES, AGENDA \& METHODOLOGY:}

The objectives of this paper include the following :

(1) To discuss a stakeholder perspective of internationalization.

(2) To identify the factors affecting the internationalization of higher education through stakeholder analysis.

(3) To attempt a systemic analysis of the supportive frameworks.

(4) To examine the divergent stakeholder attitudes towards internationalization.

(5) To study GER and Global Ranking in relation to internationalization. 
This conceptual research made use of data from secondary sources including university and $\mathrm{HE}$ institutions websites and secondary data from various publications and research databases including google scholar, ResearchGate, and Elsevier's SSRN. The postulates are developed using predictive analysis methodology on collected data and information (Shubhrajyotsna\& Aithal, 2018), Aithal \&Shubhrajyotsna, 2020) and do not need testing.

\section{A STAKEHOLDER PERSPECTIVE:}

The internationalization of higher education has become a key change agent leading to the expansion and globalization in education. Of late this has resulted in opening up the border for Foreign Direct Investment in Higher education by global service providers. The State has come into the picture through various supporting systems. These could be either inbound or outbound as the case may be depending on the strategy adopted. Thus, the internationalization of higher education is propelled by either inbound supportive systems or outbound supportive systems or both.

\section{(1) Inbound supportive systems:}

The inbound supportive activities are initiated by the government of any country aiming at strengthening institutional capabilities indigenously through creating an environment for global education service players to invest and operate. This can be implemented by attracting highly reputed and brand visible global education service players with global and regional rankings and creating an atmosphere to shift higher education models to the country. The competitive environment generated within the country by local institutions and foreign institutions together will create a foundation for improving higher education while maintaining low costs. Opening up HE system by eliminating policy-based and operation based constraints and creating open competition among the players along with offering supportive facilities such as land, long term interest-free loans, subsidies, reducing bureaucratic involvement, complete academic autonomy to HEIs, subsidised HE admission through merit and performance-based scholarships, easy educational loans to aspirants, focus on skill development and employability, etc are characteristic of inbound supportive system to improve service quality at an affordable cost and to attract youths toward higher education (Aithal \&Suresh Kumar,2016). This also enables the country to attract foreign students from other countries who can find value in availing of higher education in the country. The inbound supportive system can enhance quality education in the country as well as promote the internationalization of higher education by attracting both faculty members and students from various foreign countries. Further, in the inbound supportive system for global HE players, two strategies are observed:

(a) Foreign universities directly establish their campus in a country through Foreign Direct Investment (FDI) route. Many European universities have established their campus in some Asian and African countries through this model. But many countries have adopted an education policy which does not permit foreign universities who wanted to establish their own campus in the country through the FDI route.

(b) Foreign universities offer certain specified courses by utilizing their education model along with their faculty members in an existing university in a country by utilizing its physical infrastructure through a suitable collaborative understanding. For instance, many American and European Universities have established collaborative networks to offer their renowned courses on the local university campus of many Asian and African countries. This method is an alternative to the first method where many internationalization constraints of a foreign university in a given country can be addressed.

\section{(2) Outbound supportive system:}

The outbound supportive systems envisage creating a supportive environment for the aspiring students to take advantage of high-quality education facilities in developed countries (Kedziora, D., et al, 2017). The infrastructure, technology, experienced faculty members, their expertise, innovative and effective teaching-learning methods, pedagogy, laboratory facilities, industry interaction and international networking facilities provide a 
better learning environment for the students in foreign countries. The long experience and long saga of innovations in higher education by many old universities and institutions in developed countries also attract the citizens of developing countries for foreign education. Further, better job prospects and high earning potential are attractions. The outbound supportive system is usually utilized by either economically advantaged groups who can afford the high cost of foreign education or students who are exceptionally bright in studies and secure scholarships or financial assistance in developed countries. Thus, the outbound education supportive system allows students to go out to avail of foreign education leading to the internationalization of higher education. Like an inbound supportive system, the outbound supportive system provides two strategic opportunities to a given country.

(a) Creating a positive atmosphere through mutual agreements or financial support through long-term loans to the students of the country to avail $\mathrm{HE}$ in various foreign universities.

(b) Supporting local universities to start their campuses in other countries through suitable foreign policies for FDI either through greenfield investment or by means of acquiring an existing campus. The country can also support its local universities to develop tie-ups with existing universities in other countries to run their flagship programs in their original brand name. Countries can formulate their strategies to derive advantages and benefits by following either one or both Internationalization models in higher education. Although promoting an inbound supportive model is strategically beneficial, it takes a long time to realize this model and it is difficult to attract foreign universities to invest in the country through FDI.

\section{SYSTEMIC ANALYSIS OF SUPPORTIVE FRAMEWORKS :}

A systemic analysis of the supporting frameworks is attempted through the ABCD analysis model (Aithal, et al., 2015). ABCD model is an analysing technique that has been evolved to study a concept, system, model or institution as a case (Aithal, P. S,2016). It enables generating advantages, benefits, constraints, and disadvantages based on the segregation of a set of pertinent factors relevant to the object of study (Aithal, P. S, 2017a),(Aithal \&Shubhrajyotsna, 2018a). Both the inbound and outbound support system is separately analysed and presented in Table 2.

Table 2: Analysis of inbound and outbound models of Internationalization.

\begin{tabular}{|c|c|c|c|c|c|}
\hline \multicolumn{6}{|c|}{ INBOUND SUPPORTIVE SYSTEM } \\
\hline S1.No. & $\begin{array}{l}\text { Key } \\
\text { Actors/Factors }\end{array}$ & Advantages & Benefits & Constraints & Disadvantages \\
\hline 1. & Country & $\begin{array}{l}\text { Promotion of } \\
\text { FDI on } \\
\text { education } \\
\text { infrastructure } \\
\text { of the country }\end{array}$ & $\begin{array}{l}\text { Improved HE } \\
\text { infrastructure } \\
\text { in the country }\end{array}$ & $\begin{array}{l}\text { Countries } \\
\text { should be } \\
\text { able to attract } \\
\text { FDI from } \\
\text { global Top } \\
\text { Universities }\end{array}$ & $\begin{array}{l}\text { The increased } \\
\text { cost of HE in } \\
\text { their home } \\
\text { countries }\end{array}$ \\
\hline 2. & Institutions & $\begin{array}{l}\text { More HE } \\
\text { institutions } \\
\text { in the } \\
\text { country }\end{array}$ & $\begin{array}{l}\text { Enhanced job } \\
\text { creation locally }\end{array}$ & $\begin{array}{l}\text { Top positions } \\
\text { may be } \\
\text { occupied by } \\
\text { Foreigners }\end{array}$ & $\begin{array}{l}\text { Huge Money } \\
\text { flow to foreign } \\
\text { countries }\end{array}$ \\
\hline 3. & Students & $\begin{array}{l}\text { Increased } \\
\text { opportunities } \\
\text { for local } \\
\text { students }\end{array}$ & $\begin{array}{l}\text { Quality higher } \\
\text { education to } \\
\text { the students } \\
\text { due to } \\
\text { improved } \\
\text { teaching- } \\
\text { learning }\end{array}$ & $\begin{array}{l}\text { HE in the } \\
\text { country } \\
\text { becomes more } \\
\text { costly \& not } \\
\text { accessible by } \\
\text { poor }\end{array}$ & $\begin{array}{l}\text { Creation of gap } \\
\text { between } \\
\text { Global Private } \\
\text { university } \\
\text { graduates \& } \\
\text { Public } \\
\text { university }\end{array}$ \\
\hline
\end{tabular}




\begin{tabular}{|l|l|l|l|l|l|}
\hline & & & $\begin{array}{l}\text { process in the } \\
\text { home country }\end{array}$ & graduates \\
\hline 4. & $\begin{array}{l}\text { Educational } \\
\text { System }\end{array}$ & $\begin{array}{l}\text { Best } \\
\text { practices } \\
\text { translated to } \\
\text { the local } \\
\text { education } \\
\text { system }\end{array}$ & $\begin{array}{l}\text { Competency } \\
\text { enhanced. }\end{array}$ & $\begin{array}{l}\text { Unhealthy } \\
\text { competition } \\
\text { among the } \\
\text { Institutions }\end{array}$ & $\begin{array}{l}\text { Local HE } \\
\text { institutions } \\
\text { may not } \\
\text { sustain the } \\
\text { competition } \\
\text { due to } \\
\text { resource } \\
\text { constraints }\end{array}$ \\
\hline 5. & Infrastructure & $\begin{array}{l}\text { Support for } \\
\text { research \& } \\
\text { development } \\
\text { with access } \\
\text { to global } \\
\text { information \& } \\
\text { technology }\end{array}$ & $\begin{array}{l}\text { Enhanced } \\
\text { research } \\
\text { infrastructure } \\
\text { \& increased } \\
\text { IPR of the } \\
\text { country }\end{array}$ & $\begin{array}{l}\text { Difficulty in } \\
\text { the transfer of } \\
\text { indigenously } \\
\text { generated IPR } \\
\text { to local } \\
\text { companies }\end{array}$ & $\begin{array}{l}\text { Pressure for } \\
\text { the } \\
\text { globalization of } \\
\text { new knowledge } \\
\text { generated. }\end{array}$ \\
\hline
\end{tabular}

\begin{tabular}{|c|c|c|c|c|c|}
\hline \multicolumn{6}{|c|}{ OUTBOUND SUPPORTIVE SYSTEM } \\
\hline S1.No. & $\begin{array}{l}\text { Key } \\
\text { Actors/Factors }\end{array}$ & Advantages & Benefits & Constraints & Disadvantages \\
\hline 1. & Country & $\begin{array}{l}\text { Opportunities } \\
\text { for Growth }\end{array}$ & $\begin{array}{l}\text { Promotes } \\
\text { advanced } \\
\text { foreign } \\
\text { education in } \\
\text { the country }\end{array}$ & $\begin{array}{l}\text { Less focus on } \\
\mathrm{HE} \\
\text { infrastructure } \\
\text { development } \\
\text { locally }\end{array}$ & $\begin{array}{l}\text { Chances of } \\
\text { Brain drain to } \\
\text { other countries }\end{array}$ \\
\hline 2. & Institutions & $\begin{array}{l}\text { Supplements } \\
\text { Shortage } \\
\text { of } \\
\text { infrastructure }\end{array}$ & $\begin{array}{l}\text { Opportunity } \\
\text { to collaborate }\end{array}$ & $\begin{array}{l}\text { Expectations } \\
\text { are } \\
\text { unwieldy }\end{array}$ & $\begin{array}{l}\text { Some foreign } \\
\text { qualifications } \\
\text { are not } \\
\text { acceptable in } \\
\text { the home } \\
\text { country }\end{array}$ \\
\hline 3. & Students & $\begin{array}{l}\text { Better } \\
\text { opportunities } \\
\text { for people who } \\
\text { can afford the } \\
\text { cost }\end{array}$ & $\begin{array}{l}\text { Global } \\
\text { exposure for } \\
\text { higher } \\
\text { education \& } \\
\text { networking }\end{array}$ & $\begin{array}{l}\text { Only a few } \\
\text { students can } \\
\text { afford the cost } \\
\text { of foreign } \\
\text { education }\end{array}$ & $\begin{array}{l}\text { Good students } \\
\text { may be } \\
\text { deprived of } \\
\text { high-quality } \\
\text { education and } \\
\text { global } \\
\text { employment }\end{array}$ \\
\hline 4. & $\begin{array}{l}\text { Education } \\
\text { System }\end{array}$ & $\begin{array}{l}\text { Absorption of } \\
\text { global } \\
\text { technology \& } \\
\text { lifestyle }\end{array}$ & $\begin{array}{l}\text { Become } \\
\text { destinations } \\
\text { of choice }\end{array}$ & $\begin{array}{l}\text { Adjustment } \\
\text { may be } \\
\text { challenging }\end{array}$ & $\begin{array}{l}\text { Most of the } \\
\text { students who } \\
\text { go for foreign } \\
\text { education will } \\
\text { not come back } \\
\text { to serve the } \\
\text { country }\end{array}$ \\
\hline 5. & Infrastructure & $\begin{array}{l}\text { Access to } \\
\text { developed } \\
\text { research } \\
\text { infrastructure }\end{array}$ & $\begin{array}{l}\text { Opportunity } \\
\text { to contribute } \\
\text { ideas and } \\
\text { knowledge }\end{array}$ & $\begin{array}{l}\text { Staying in a } \\
\text { foreign } \\
\text { country and } \\
\text { the loneliness } \\
\text { due to } \\
\text { changes in } \\
\text { environment } \\
\text { and culture }\end{array}$ & $\begin{array}{l}\text { Research } \\
\text { performance } \\
\text { may be low } \\
\text { due to working } \\
\text { with new } \\
\text { teams, } \\
\text { communities } \\
\text { and the } \\
\text { environment }\end{array}$ \\
\hline
\end{tabular}




\section{STAKEHOLDER ANALYSIS :}

Stakeholder analysis enables to bring out the concerns and demands placed on various stakeholders of an organization or a system. Nine categories of stakeholders are subject to analysis here. A distinction is made between the 'affecting factors' and 'critical constituent elements' (Aithal \&Shubhrajyotsna, 2018a), Aithal, P. S, 2017b). Affecting factors for each stakeholder indicates how stakeholders affect or are affected by internationalization. This also indicates the nature of concerns and demands which has to be addressed to facilitate better adjustment (Galushka, Z. et al, 2016). The critical constituent elements are critical to addressing the issues expressed in the affecting factors. They explain the manner in which the concerns and demands would be met in their ability to function. The analysis is undertaken in the framework of inbound and outbound support systems separately so that the affecting factors best convey the true characteristics of two contrasting situations.

Table 3: Affecting factors of Inbound supportive systems

\begin{tabular}{|l|l|l|l|}
\hline $\begin{array}{l}\text { S1. } \\
\text { No. }\end{array}$ & Stakeholders & Affecting Factor & $\begin{array}{l}\text { Critical Constituent } \\
\text { Elements }\end{array}$ \\
\hline 1 & Home Country & Vertical Expansion & $\begin{array}{l}\text { Acceptability, } \\
\text { Necessity }\end{array}$ \\
\hline 2 & Host Country & Enabling Environment & $\begin{array}{l}\text { Readiness, } \\
\text { Participation }\end{array}$ \\
\hline 3 & $\begin{array}{l}\text { Investing/Host } \\
\text { University }\end{array}$ & Brand Building & $\begin{array}{l}\text { Reputation, } \\
\text { Trend-Setting } \\
\text { Student Preference, } \\
\text { Novelty of Courses }\end{array}$ \\
\hline 4 & Home Universities & $\begin{array}{l}\text { Opportunity for } \\
\text { Advancement }\end{array}$ & $\begin{array}{l}\text { Motivation, } \\
\text { Career Goals }\end{array}$ \\
\hline 5 & Students & Expanding Choices & $\begin{array}{l}\text { Cost, } \\
\text { Quality }\end{array}$ \\
\hline 6 & Parents & Economy & $\begin{array}{l}\text { Flexibility, } \\
\text { Expansion }\end{array}$ \\
\hline 7 & Foreign Competitors & Safe Positioning & $\begin{array}{l}\text { Identity, } \\
\text { Operation }\end{array}$ \\
\hline 8 & Local Competitors & Threat Perception & $\begin{array}{l}\text { Equity, } \\
\text { Development }\end{array}$ \\
\hline 9 & State & Value Creation & \\
\hline
\end{tabular}

Table 4: Affecting factors of Outbound supportive systems

\begin{tabular}{|l|l|l|l|}
\hline S. No. & Stakeholders & Affecting Factor & $\begin{array}{l}\text { Critical Constituent } \\
\text { Elements }\end{array}$ \\
\hline 1 & Home Country & Financial Implications & $\begin{array}{l}\text { Unlimited Demand, } \\
\text { Growing Numbers }\end{array}$ \\
\hline 2 & Host Country & Ensuring Preparedness & $\begin{array}{l}\text { New Opportunities, } \\
\text { New Challenges }\end{array}$ \\
\hline 3 & Students & Encashing Opportunity & $\begin{array}{l}\text { Academic Merit, } \\
\text { Economic Means }\end{array}$ \\
\hline 4 & Parents & Hopes and Dilemma & $\begin{array}{l}\text { Future Prospects, } \\
\text { Ability to Support }\end{array}$ \\
\hline 5 & Host University & Balancing Concerns & $\begin{array}{l}\text { Ability to Cater, } \\
\text { Losing on Proportion }\end{array}$ \\
\hline 6 & Foreign Competitors & Greater Competition & $\begin{array}{l}\text { Liberal Policies, } \\
\text { Increased Attraction }\end{array}$ \\
\hline 7 & Industry & Pressure to Sustain & $\begin{array}{l}\text { New Strategies, } \\
\text { Rivalry }\end{array}$ \\
\hline 8 & State & Derive Optimum Benefit & $\begin{array}{l}\text { Containing Cost, } \\
\text { Expanding Coverage }\end{array}$ \\
\hline
\end{tabular}




\section{EFFECT OF GLOBAL RANKING ON INTERNATIONAIZATION OF HIGHER}

\section{EDUCATION :}

The quest for quality education and the search for innovation in higher education has fueled the internationalization of higher education. The internationalization of $\mathrm{HE}$ is included in the global rankings by many ranking agencies. The ranking is done based on three distinguishable parametric criteria such as (1)Teaching-learning process(2)Research output (Boden, R., et al, 2006), and(3)Internationalization (Yemini, M., et al, 2016). Table 5 gives an idea of major ranking agencies and weightage of various criteria based on the chosen performance indicators on the internationalization of higher education. Table 6 contains the different performance indicators used by global university ranking agencies for evaluating the contribution to the internationalization of higher education. On average internationalization gets 10 percent of the weightage. Adding to the specific scores that an institution secures in the other criteria, it becomes a significant determinant in the overall ranking. The performance indicators for measuring the level of internationalization include the number of international students, faculty, among others (Aithal \&.Suresh Kumar,2020).

Table 5: List of ranking agencies and their weightage for internationalization of $\mathrm{HE}$

\begin{tabular}{|c|c|c|c|c|}
\hline $\begin{array}{l}\text { S. } \\
\text { No. }\end{array}$ & Ranking Agencies & $\begin{array}{l}\text { Weightage } \\
\text { for } \\
\text { Teaching- } \\
\text { learning }\end{array}$ & $\begin{array}{l}\text { Weightage } \\
\text { for } \\
\text { Research } \\
\text { output }\end{array}$ & $\begin{array}{l}\text { Weightage for } \\
\text { Internationalization }\end{array}$ \\
\hline 1 & $\begin{array}{l}\text { Times Higher Education } \\
\text { Ranking model, UK }\end{array}$ & $30 \%$ & $60 \%$ & $7.5 \%$ \\
\hline 2 & $\begin{array}{l}\text { QS World University } \\
\text { Ranking model, UK }\end{array}$ & $40 \%$ & $20 \%$ & $10 \%$ \\
\hline 3 & $\begin{array}{l}\text { Round University Ranking } \\
\text { (RUR), Russia }\end{array}$ & $40 \%$ & $40 \%$ & $10 \%$ \\
\hline 4 & $\begin{array}{l}\text { U.S. News \& World Report's } \\
\text { Best Global Universities } \\
\text { Ranking (USA) }\end{array}$ & No & $90 \%$ & $10 \%$ \\
\hline 5 & $\begin{array}{l}\text { Global University Ranking, } \\
\text { Russia }\end{array}$ & $20 \%$ & $20 \%$ & $10 \%$ \\
\hline
\end{tabular}

Table 6: Internationalization as a performance indicator

\begin{tabular}{|c|c|c|c|}
\hline $\begin{array}{l}\text { S. } \\
\text { No. }\end{array}$ & Ranking Agencies & $\begin{array}{l}\text { Weightage for } \\
\text { Internationalizati } \\
\text { on }\end{array}$ & Performance Indicators $\&$ weightage \\
\hline 1 & $\begin{array}{l}\text { Times Higher } \\
\text { Education Ranking } \\
\text { model, UK }\end{array}$ & $7.5 \%$ & $\begin{array}{l}\text { - Percentage of international students: } \\
2.5 \% \\
\text { - Percentage of international staff : } \\
2.5 \% \\
\text { - International collaboration : } 2.5 \%\end{array}$ \\
\hline 2 & $\begin{array}{lr}\text { QS } & \text { World } \\
\text { University Ranking } \\
\text { model, UK }\end{array}$ & $10 \%$ & $\begin{array}{l}\text { - International Faculty } \\
\text { - International Student Ratio }\end{array}$ \\
\hline 3 & $\begin{array}{lr}\begin{array}{l}\text { Round } \\
\text { Ranking } \\
\text { Russia }\end{array} & \text { (RUR), } \\
& \end{array}$ & $10 \%$ & 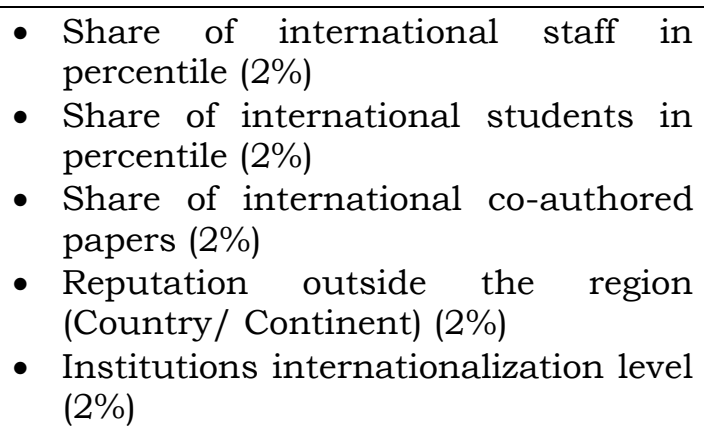 \\
\hline 4 & U.S. News \& World & $10 \%$ & - International collaboration-relative \\
\hline
\end{tabular}




\begin{tabular}{|l|l|l|l|}
\hline & $\begin{array}{l}\text { Report's Best } \\
\text { Global Universities } \\
\text { Ranking (USA) }\end{array}$ & & $\begin{array}{l}\text { to country. } \\
\text { International } \\
\text { publications }\end{array}$ \\
\hline 5 & $\begin{array}{l}\text { Global University } \\
\text { Ranking, Russia }\end{array}$ & $10 \%$ & $\begin{array}{l}\text { International Activities like : } \\
\text { Membership of a university in the } \\
\text { international academic communities } \\
\text { - Number of foreign students from an } \\
\text { aggregate number of students. }\end{array}$ \\
\hline
\end{tabular}

\section{ENHANCING GER THROUGH THE PROCESS OF INTERNATIONALIZATION:}

It is suggested that countries have emphasized an inbound supportive system to attract foreign universities to invest in higher education. Concurrently, countries encourage local universities to improve their physical, digital, teaching-learning, IPR, emotional and networking infrastructure, to compete with foreign universities. This creates a competitive environment within the country for improved quality of higher education at a decreased cost. This also attracts many students to stay back in the country for their higher education, resulting in an improved Gross Enrollment Ratio (GER) of the higher education system of the country. The increased competition improves the quality of higher education in the country. This helps to maintain better economic status in the country. This also creates more job opportunities for local people due to foreign universities investment and corresponding economic growth in the country. On the other hand, if the country focuses more on the outbound supportive system, the local higher education quality does not improve due to low competition internally and hence many local students migrate to other countries which increases the outgoing of the huge amount of money without much benefit locally.

\section{STAKEHOLDER ATTITUDE TOWARDS INTERNATIONALIZATION :}

Stakeholder attitude is manifested through its approaches and actions in all realms of its operation, which promote internationalization. Such, for instance, are the following :

(1) International students: The host country and those of the participating students display a positive and proactive attitude. This would enhance enrollment and act as a catalyst in the process.

(2) International faculty: Just as international students matter, faculty also add to the diversity of the learning environment. Institutions with a global outlook always try to attract faculty from far and wide.

(3) Institutional Partnerships: Collaboration between nations as well as institutional partnerships are favourable to the goals of internationalization in multiple ways. Institutions could be good comraderies responding to the needs of expertise.

(4) Collaborative publications: Research and publications are part and parcel of the objectives of higher education. New knowledge is generated and dissipated to a wider audience through publications. It is a direct measure of the involvement in intellectual activity pursued by the faculty.

(5) Internship opportunities: This is an added avenue to promote internationalization where cost could be compensated by contribution through service.

(6) International conferences: Conferences act as an interactive forum for scholars to get to know the place (institutional location), people (academia and their expertise) and work (studies and researches). It servers to publicize the institution's profile as one of the key players.

(7) Earnings through Consultancy: This is one of the ways by which institutions can generate earning by encashing their competence. It also provides faculty to enhance their 
expertise and institutions to share the outcome. It fulfills the institution's responsibility and commitment to society.

(8) Image and Reputation: Both institutions and host countries welcoming international scholars bring repute for their services and standards that have been built over time. A relentless pursuit is required to sustain it as well.

(9) Fellowships \& Scholarships: A lot of flexibility is demanded from state and institutions to promote international mobility for learning primarily that of providing economic means through scholarship and assistance to students.

(10) Infrastructure and facilities: The swelling number of students necessitate the creation of improved infrastructure and facilities, such as accommodation, amenities, study spaces, and recreational facilities.

Universities in different countries can incorporate one or more above components in their objectives of internationalization of higher education.

\section{CONCLUSION :}

The internationalization of higher education has opened up new challenges for stakeholders. Two models emerge in the practice, namely inbound and outbound. Analysis of inbound and outbound models as support systems helps us to weigh the advantages and benefits of both these as opposed to their constraints and disadvantages. This has implications for formulating policies by institutions and the state. Stakeholder analysis through the 'Affecting factor framework' brings to light the role of constituent elements that need to be addressed to facilitate the better adjustment. Systemic analysis portrays the advantages and disadvantages that it might cause to the key actors involved in internationalization in the inbound and outbound models. Stakeholder attitude reflects possibilities to evolve strategies to derive the best benefit. From a stakeholder perspective, internationalization is a "planned, motivated and goal-oriented approach to attaining learning while at the same time fulfilling stakeholder interest in a mutually satisfying manner, in trans-national context". Financial imperatives notwithstanding, it is found to be gainful for all stakeholders.

\section{REFERENCES :}

[1]. Aithal, P. S. (2015). Concept of Ideal Business \& Its Realization Using E-Business Model. International Journal of Science and Research (IJSR), 4(3), 1267 - 1274.

[2]. Aithal P. S. and Shubhrajyotsna Aithal (2015). An Innovative Education Model to realize Ideal Education System. International Journal of Scientific Research and Management (IJSRM), 3(3), 2464 - 2469.

[3]. Aithal, P. S., Shailashree, V.T. \& Suresh Kumar, P. M. (2015). A New ABCD Technique to Analyze Business Models \& Concepts. International Journal of Management, IT and Engineering (IJMIE), 5(4), $409-423$.

[4]. Aithal, P. S. (2016). Study on ABCD Analysis Technique for Business Models, business strategies, Operating Concepts \& Business Systems. International Journal in Management and Social Science, 4(1), 98-115.

[5]. Aithal, P. S. \&Suresh Kumar, P. M. (2016). Catering Student Enrollment and Retaining Diversity in Higher Education Institutions, International Journal of Engineering Research and Modern Education (IJERME), 1(1), 565 - 577.

[6]. Aithal, P. S. (2017a). ABCD Analysis of Recently Announced New Research Indices. International Journal of Management, Technology, and Social Sciences (IJMTS), 1(1), 65-76.

[7]. Aithal, P. S. (2017b). Factor Analysis based on ABCD Framework on Recently Announced New Research Indices, International Journal of Management, Technology, and Social Sciences (IJMTS), 1(1), 82-94.

[8]. Aithal, P. S., \&.Shubhrajyotsna Aithal (2018a). Factor \& Elemental Analysis of Nanotechnology as Green Technology using ABCD Framework. International Journal of Management, Technology, and Social Sciences (IJMTS), 3(2), 57-72.

[9]. Aithal, P. S. \& Shubhrajyotsna Aithal (2018b). The Concept \& Characteristics of Ideal Energy System and its Realization Constraints. International Journal of Applied Engineering and Management Letters (IJAEML), 2(2), 127-137. 
[10]. Aithal P. S., \&ShubhrajyotsnaAithal (2020). Promoting Faculty and Student-Centered Research and Innovation based Excellence Model to Reimage Universities. International Journal of Management, Technology, and Social Sciences (IJMTS), 5(1), 24-41.

[11]. Aithal, P. S., \&Suresh Kumar P. M. (2020). Global Ranking and its Implications in Higher Education. SCHOLEDGE International Journal of Business Policy \& Governance, 07(03), 25-47.

[12]. Altbach, P. G. (2004). Globalisation and the university: Myths and realities in an unequal world. Tertiary Education \& Management, 10(1), 3-25.

[13]. Altbach, P. G., Reisberg, L., \&Rumbley, L. E. (2009). Trends in global higher education: Tracking an academic revolution. UNESCO Publishing, The Netherlands.

[14]. Aziz, M. I. A., \& Abdullah, D. (2014). Finding the next 'wave' in internationalisation of higher education: Focus on Malaysia. Asia Pacific Education Review, 15(3), 493-502.

[15]. Boden, R., \& Epstein, D. (2006). Managing the research imagination? Globalisation and research in higher education. Globalisation, Societies and Education, 4(2), 223-236.

[16]. Bradford, H., Guzmán, A., \& Trujillo, M. A. (2017). Determinants of successful internationalisation processes in business schools. Journal of Higher Education Policy and Management, 39(4), 435-452.

[17]. Deem, R., Mok, K. H., \& Lucas, L. (2008). Transforming higher education in whose image? Exploring the concept of the 'world-class' university in Europe and Asia. Higher education policy, 21(1), 83-97.

[18]. de Wit, J. H. (2011). Globalization and internationalisation of higher education. RUSC. Universities and Knowledge Society Journal, 8(2), 77-164.

[19]. Galushka, Z., \&Sobolev, V. (2016). Factors of Competitiveness of Universities Under Administration, 16(3), 106-110.

[20]. Gatfield, T., \& Chen, C. H. (2006). Measuring student choice criteria using the theory of planned behaviour: The case of Taiwan, Australia, UK, and USA. Journal of Marketing for Higher Education, 16(1), 77-95.

[21]. Jones, E., \& Killick, D. (2013). Graduate attributes and the internationalized curriculum: Embedding a global outlook in disciplinary learning outcomes. Journal of Studies in International Education, 17(2), 165-182.

[22]. Kedziora, D., Klamut, E., Karri, T., \&Kraslawski, A. (2017). Higher education offshoring as an innovative response to global learning challenges. International Journal of Management, Knowledge and Learning, 6(2), 239-260.

[23]. Knight, J., \& De Wit, H. (2018). Internationalization of higher education: Past and future. International Higher Education, (95), 2-4.

[24]. Maringe, F. (2010). The meanings of globalization and internationalization in HE: Findings from a world survey. Globalization and internationalization in higher education: Theoretical, strategic and management perspectives, Bloomsbury Publishing plc., 17-34.

[25]. Nicolescu, L., Pricopie, R., \& Popescu, A. I. (2009). Country differences in the internationalization of higher Education-How can countries lagging behind diminish the gap. Review of International Comparative Management, 10(5). 976-989.

[26]. Seeber, M., Cattaneo, M., Huisman, J., \&Paleari, S. (2016). Why do higher education institutions internationalize? An investigation of the multilevel determinants of internationalization rationales. Higher education, 72(5), 685-702.

[27]. Shams, S. R., \& Hasan, R. (2020). Capacity building for transnationalisation of higher education. European Business Review, 32 (3), 459-484.

[28]. Shubhrajyotsna Aithal \& Aithal, P. S. (2018). The Realization Opportunity of Ideal Energy System using Nanotechnology Based Research and Innovations. International Journal of Advanced Trends in Engineering and Technology, 3(2), 1-15.

[29]. Stella, A., \&Gnanam, A. (2005). Cross-border Higher Education in India: False understandings and true overestimates. Quality in higher education, 11(3), 227-237.

[30]. Teichler, U. (2004). The changing debate on internationalisation of higher education. Higher education, 48(1), 5-26.

[31]. Wihlborg, M. (2009). The pedagogical dimension of internationalisation? A challenging quality issue in higher education for the twenty-first century. European Educational Research Journal, 8(1), 117-132.

[32]. Yemini, M., \&Sagie, N. (2016). Research on internationalisation in higher educationexploratory analysis. Perspectives: Policy and Practice in Higher Education, 20(2-3), 90-98. 